\title{
Recent Developments in Corporate Governance Codes in the GCC Region
}

\author{
Mohammed Haitham A. Salman ${ }^{1} \&$ Haitham Nobanee ${ }^{1}$ \\ ${ }^{1}$ College of Business, Abu Dhabi University, Abu Dhabi, United Arab Emirates \\ Correspondence: Haitham Nobanee, College of Business, Abu Dhabi University, P.O. Box 59911, Abu Dhabi, \\ United Arab Emirates.
}

Received: June 25, 2019

Accepted: August 30, $2019 \quad$ Online Published: September 28, 2019

doi:10.5430/rwe.v10n3p108

URL: https://doi.org/10.5430/rwe.v10n3p108

\begin{abstract}
This paper aims to examine recent developments in corporate governance codes in the Gulf Cooperation Council (GCC) region and evaluate to what extent these changes are in line with the G20/OECD Principles of Corporate Governance 2015 Edition. The paper employed an analytical comparative approach, the results show all GCC countries, except Bahrain, have recently updated their CG codes. Bahrain needs to update its current CG code in terms of the rights of both shareholders and stakeholders to be in line with international best practice. Efforts in the GCC region to enhance $\mathrm{CG}$ in listed companies should be continued and expanded to cover state-owned enterprises, sovereign wealth funds, and banks. The findings would be useful to the financial managers in the GCC in complying with the recent developments in corporate governance codes and in developing guidelines for appropriate disclosure to improve the reporting quality.
\end{abstract}

Keywords: corporate governance, GCC Region, shareholder rights and obligations, GCC States, G20/OECD principles of corporate governance, companies law, corporate governance code

JEL Classification: C33, G32, G34

\section{Introduction}

The Cooperation Council for the Arab States of the Gulf (GCC) is a regional organisation formed in 1981, which comprises six States: the Kingdom of Saudi Arabia (KSA), the United Arab Emirates (UAE), Oman, Bahrain, Kuwait, and Qatar. These states share similar characteristics in terms of religion (Islam), ethnicity (Arab), political regime (monarchy), economic structure (all of them are heavily dependent on oil exports as the main source of fiscal revenues), traditions and culture. However, despite these similarities, they are different in terms of population, oil production, the size of their economies, the level of their reliance on oil revenues and other factors.

The recent sharp fall in the international oil price, from 110 USD in mid-2014 to around 50 USD in mid-2015 and to around 40 USD in 2016 (Statistics Portal, 2017), economically affects all GCC states at different levels (IMF, 2016). To enhance economic diversification away from oil, GCC states have been implementing many structural reforms to improve business infrastructure and to increase the role of the private sector in their national economies. These reforms include, but are not limited to, streamlining business procedures to reduce the cost of doing business, deregulating Foreign Direct Investment (FDI) restrictions to attract targeted FDI inflows, strengthening corporate legislation and government supervision (five GCC states issued new company laws during 2015-2016), and various legislative updates to improve national competitiveness in global business ratings and indicators (IMF, 2016).

Five GCC states have recently updated their Corporate Governance (CG) codes to be consistent with recent developments in CG worldwide, in order to improve the attractiveness of their business environments for FDI inflows, as well as to have access to capital markets with low funding costs. Not only are these updated codes in line with the reforms mentioned above, they are also in response to criticism of CG in public joint stock companies in the GCC states, mainly due to the lack of effective independent boards, weak transparency, disclosure practices (Fitch Ratings, 2014), and insufficient oversight and scrutiny of key enterprise risks (S\&P, 2017).

\subsection{Corporate Governance (CG) Worldwide}

CG is a combination of legislation, regulations, rules and voluntary business practices within entities in the private sector (Aldin et al., 2014; Nobanee and Ellili, 2014). CG can be simply defined as the set of rules and actions that 
help companies ensure their business operations are ethical and take care of the interests of stakeholders (shareholders, employees, customers, and banks). The application of CG is widely considered a long-term business sustainability mechanism for business entities (Kumar and Sharma, 2006; Nobanee and Ellili, 2016).

The principles of CG are not identical among countries, due to differences in economic, political and other aspects of each country. Therefore, it is not possible to give one definition (Alzahrani, 2013). However, the Organization for Economic Co-operation and Development (OECD), in partnership with G20 (the countries of G7 plus developing nations such as Brazil, China, India, Russia, and KSA), recently defined CG in the OECD Principles of CG of 2015 as:

CG involves a set of relationships between a company's management, its board, its shareholders, and other stakeholders. CG also provides the structure through which the objectives of the company are set, and the means of attaining those objectives and monitoring performance are determined. (OECD, 2015)

In the last two decades, the discovery of various financial and accounting scandals like WorldCom, Enron, Lehman Brothers and the misbehaviour of corporate executive management in many corporations worldwide have dramatically increased the need for corporations worldwide to develop and adopt sound CG. To facilitate the application of CG and to avoid uncertainty and misunderstanding of the scope of CG, as it is usually regulated by corporate laws and by other statutory instruments, countries around the world have adopted national CG codes which streamline all related requirements stated in legislation and corporate law in a commonly understandable code (Aldin et al., 2014). According to the database of the European Corporate Governance Institute (ECGI), more than 100 countries have their own national CG code. These codes are under constant change and development, due to the needs of each country and the best practices of CG worldwide (ECGI, 2017).

The OECD has resumed its efforts to review and develop the principles of CG, provided in the first edition published in 1999, and conducted an intensive, comprehensive review during 2014/15, with significant contributions from representatives of non-OECD G20 countries, experts from relevant international organizations, such as the Financial Stability Board, World Bank Group, experts from developing countries in Latin America, Asia, the Middle East, and North Africa, and various business and industry advisory committees. The final draft of the G20/OECD Principles of CG was endorsed by G20 leaders at the Antalya Summit on 15-16 November 2015. The updated principles are mainly:

A - focussed on publicly traded companies, both financial and non-financial. They can be also used by companies whose shares are not publicly traded.

B - intended to help policymakers evaluate and improve the legal, regulatory, and institutional framework for CG.

$\mathrm{C}$ - intended to be concise, understandable and accessible to the international community.

D - recognising the interests of employees and other stakeholders and their important role in contributing to the long-term success and performance of the company.

E - developed with the understanding of the important role CG plays in achieving broader economic objectives in terms of investors' confidence, capital formation, and allocation.

$\mathrm{F}$ - formulated to embrace the different models of $\mathrm{CG}$ that exist.

$\mathrm{G}$ - intended to be non-binding and just seek to identify objectives and suggest various means for achieving them.

The updated principles are presented in six different chapters, as follows:

I) Ensuring the basis for an effective CG framework;

II) The rights and equitable treatment of shareholders and key ownership functions;

III) Institutional investors, stock markets, and other intermediaries;

IV) The role of stakeholders;

V) Disclosure and transparency; and

VI) The responsibilities of the board.

The updated principles under G20/OECD 2015 are widely used as a benchmark by national jurisdictions around the world (OECD, 2015). 
This paper is divided into five sections: the next section provides a general introduction to CG in the GCC region and this is followed by the main developments in CG codes in GCC states. The next section provides a comparative analysis of the recent developments in CG codes in GCC states and this is followed by a comparison of current CG codes in GCC states with the G20/OECD Principles of Corporate Governance 2015 Edition. Finally, the conclusion is presented.

\section{Corporate Governance in the GCC}

CG was first addressed in the GCC states in 2002 when Oman issued the first CG code for listed companies (Shehata, 2015). Most GCC states followed Oman and issued CG codes in 2006 and 2007. According to Saidi and Kumar (2007), the CG frameworks in GCC states varied and were at different levels of development, due to the dominance of family-owned enterprises, the underdeveloped capital market with weak regulatory environments, and isolation from the global market.

Cossin and El-Agamy (2011) stated that the development of CG in the Middle East and North Africa, including the GCC states, was driven by the need to attract FDI, particularly among non-oil producing countries, the development of financial markets, and the increasing competition to family businesses due to globalization. Cossin and El-Agamy (2011) expected that, due to these driving factors, the region would witness a second wave of CG development, focussing on improving practices and behaviours in managing business corporations in line with regional cultural values, as well as caring and effective management for all parts of society.

Since the fall in international oil prices and the increasing need to attract FDI to enhance the role of the private sector, all GCC states have made intensive efforts to improve and update their corporate legislation and national CG codes, in accordance with the international best practices as detailed later in this paper.

Most of the CG codes in GCC states are based on the principle of "comply-or-explain", under which companies are required to disclose the extent to which they comply with the provisions of the code. If a company does not comply with any provision of the code, it must identify which provisions or articles are not complied with, and justify and explain the reasons and rationales behind its non-compliance.

\subsection{Main Developments in CG Codes in GCC States}

\subsubsection{Oman}

Oman was the first country in the GCC region to adopt a CG code for companies listed on the Muscat Securities Market, in 2002. The code was slightly amended by Circular No. 1 of 2003 under the name of Omani Corporate Governance Code, Edition 4 of 2010 (ECGI, 2017).

Due to the increasing need to improve the commercial environment after the fall of oil prices, the Capital Market Authority (CMA) issued an updated CG Code entitled "Code of Corporate Governance for Publicly Held Joint Stock Companies" in July 2015, which replaced the old CG code of 2002 and entered into force on 22 July 2016. The new code, which consists of 14 principles with three annexes, provides the following main changes:

A - Board of Directors (BoD):

- Providing a requirement that all $\mathrm{BoD}$ members should be non-executive and one third should be independent members;

- Detailing the roles and responsibilities of the BoD, the necessary skills and competencies of both the chairman and the members of the BoD;

- The training required for newly appointed BoD members;

- The standards of professional conduct of directors and executives as detailed under Annex No. 2, which covers the following duties: professionalism, due diligence, integrity, conflict of interests, compliance with the law, and access to information;

$\mathrm{B}$ - Defining related parties and the approval procedures regarding related party transactions;

C - Detailing the key functions of the audit committee;

D - Setting out the requirements for a nomination and remuneration committee with all details about the functions of the committee, including advising on policies related to remuneration and rewards;

E - Setting out the requirements to develop a charter addressing social responsibility policy, including adopting an annual plan or strategy; 
F - Setting out the requirements for the company's annual report to contain a separate chapter, with specific items, on the company's compliance with the CG code.

However, shareholders' rights, which are considered one of the main elements of CG codes worldwide are not covered in the updated Omani CG code.

\subsubsection{Kingdom of Saudi Arabia (KSA)}

KSA is the biggest economy in the GCC region and a member of G20. In 2006, the Saudi Arabian Capital Market Authority (SACMA) issued "Saudi Corporate Governance Regulations", the second CG code in the GCC region after Oman. The code was initially applicable to public joint stock listed companies on a voluntary basis and particularly proposed to prevent further crashes in the stock market (ECGI, 2017). By 2010, implementation of the CG code became compulsory for all listed companies (Alzahrani, 2013). The code was based on a comply-or-explain basis and consisted of 19 articles, which generally covered the main five principles of the OECD Principles (Hussainey and Al-Nodel, 2008).

In line with KSA's continued efforts to diversify its economic resources and encourage FDI inflows, SACMA issued an updated and detailed CG code that is consistent with the provisions of the new Companies Law of 2015, applicable to public joint stock companies listed on the market. The new CG code replaced the previous one and came into effect on 22 April 2017, while enforcement of the provisions which require companies to draft and publish CG policies came into force on 31 December 2017. The new code, taking into consideration KSA's membership of the G20, who participated in developing the G20/OECD Corporate Governance, takes account of international developments in the CG field and best practice worldwide. The impact of the new code is likely to be significant, especially when compared with the old CG infrastructure (Dechert LLP, 2017). It is a very detailed code, with 98 articles distributed in 12 chapters. The main changes brought by the new CG code can be summarized as follows:

A - Detailing the rights of shareholders, both the common general rights as well as rights regarding General Assembly Meetings (GAMs), including ordinary and extraordinary meetings, meeting notifications, meeting agenda, meeting management, and the publication of the resolutions as required by SACMA;

B - BoD chapter, which mainly details the following:

- The formation of a BoD which should have no less than 3 and no more than 11 members, the majority of whom should be non-executive;

- The roles and duties of the chairman and members of the BoD;

- The competencies of the BoD members, including the ability to lead, financial knowledge, physical fitness, and issues which affect the independence of members;

- The main functions of the BoD, including laying down plans, policies, strategies, key business plans, determining the capital structure, overseeing the main capital expenditures, setting performance indicators as well as other values and standards in the company;

- The BoD's compliance with the principles of truthfulness, honesty, and loyalty;

- The procedures of BoD activities, including board meetings, attendance of BoD, agenda of board meetings, and the secretary and his qualifications;

- Training, support, and assessment of BoD;

- Disclosure requirement for conflicts of interest and related party transactions.

D - Company committees chapter, which mainly details all the issues related to BoD committees (i.e. auditing, remuneration, nomination, and risk management), including the formation, structure, functions, competencies, meetings, and remunerations of the members.

E - Setting up an internal control system, including the establishment of a unit independent of the company, the duties of the internal audit unit, plans, and reports;

F - Appointing an external auditor, including the functions of auditors, the qualifications and professional duties of the external auditor;

$\mathrm{G}$ - Stakeholders, including regulation of relationships with stakeholders, reporting non-compliant practices, and employee incentives;

$\mathrm{H}$ - Professional and ethical standards, including setting up a policy for professional conduct and ethical values at the company, social responsibility as well as social initiatives; 
I - Disclosure and transparency, including policies and procedures for disclosure, BoD's report, audit committee's report, disclosure by BoD, and disclosure of remunerations;

$\mathrm{J}$ - Implementation of CG, including the implementation of effective governance, the formation of a corporate governance committee, retention of documents. Under Appendix 1, the code provides a schedule for the remuneration of both $\mathrm{BoD}$ and senior executives.

\subsubsection{United Arab Emirates (UAE)}

The efforts to draft a CG code for listed companies started in 2004 and the first CG code, titled "Governance Rules and Corporate Governance Discipline Standards", was issued under Ministerial Resolution No. 518 of 2009 and was effective from 30 April 2010 (ECGI, 2017). In March 2015, a new Federal Commercial Companies Law was issued, aiming to develop the business environment by organizing companies in accordance with international best practice, especially in relation to the organization of governance rules, the protection of the rights of shareholders and partners, support of foreign investment inflows and improvement of corporate social responsibility (Article 2, Federal Commercial Companies Law No. 2 of 2015). The law has given the Securities and Commodities Authority (SCA) full authority to license and regulate the operation of joint stock companies, including issuing the regulations related to CG (Article 6, Federal Commercial Companies Law No. 2 of 2015).

In line with this effort, in April 2016, the Chairman of the SCA issued Resolution No. 7 R.M. of 2016, "Concerning the Standards of Institutional Discipline and Governance of Public Shareholding Companies" to be applied with immediate effect. The resolution has 55 articles distributed in three chapters. The resolution entails the following main changes:

A - BoD:

- Detailing the roles, necessary skills, and the competencies of the chairman and the members of the BoD;

- At least one-third of BoD members shall be independent members and a majority shall be non-executive members, who have the technical skills and experience required to serve the interests of the company;

- The requirement for not less than $20 \%$ of members to be female, or the $\mathrm{BoD}$ needs to justify its non-compliance;

- Detailing other aspects related to the BoD, including meetings, using modern technology, making decisions, minutes of meetings, a delegation of authority, the vacancy of members, and obtaining the opinion of an external consultant;

- Detailing the professional and ethical duties of BoD members;

- Remuneration of the chairman and the members of BoD;

B - Defining related parties and the approval procedures required to approve related party transactions;

$\mathrm{C}$ - Detailing aspects of GAMs, including the invitations, minutes of the meetings, duration of authority delegation, meeting arrangement, listing items, issuing special resolutions, implementation of resolutions, and increasing the company's capital;

$\mathrm{D}$ - Detailing shareholders' rights and the necessary procedures to maintain these rights;

E - The requirement to appoint a person to deal with relations with investors, defining the skills and the information required to be provided to investors;

F - Detailing the qualifications and duties of the external auditor, as well as the scope of his services to the company;

$\mathrm{G}$ - The requirements for a nomination and remuneration committee, which comprises at least three non-executive members, with further details about the committee's role, including advising on policies related to remunerations and rewards.

Although Article No. 242 of the Federal Commercial Companies Law No. 2 of 2015 permits public joint stock companies to make voluntary social contributions in certain circumstances, providing they do not exceed $2 \%$ of the average net profits of the company during the two financial years preceding the year when the voluntary contribution is made, the SCA Resolution does not stipulate any provisions in this regard in the CG code. 


\subsubsection{Qatar}

The BoD of the Qatar Financial Market Authority (QFMA) issued the first CG code for companies listed in the financial market of Qatar in 2009, which was based on international best practice and the existing national legal infrastructure (ECGI, 2017).

In line with the recent global and regional trend to develop CG infrastructure, a new Commercial Companies Law has been promulgated under Law No. 11 of 2015, which formally sets up the updated legislative infrastructure for CG in the state. In accordance with the new Companies Law, the QFMA Board issued its Decision No. 5 of 2016 "Concerning the Issuance of CG Code for Companies and Legal Entities Listed on the Main Market", which became effective from 10 November 2016 (QFMA, 2016). As stated in the preamble, the updated code considered the best international and regional codes of CG governance and the principles developed by the G20/OECD, the Bank for International Settlements of 2015, and the International Corporate Governance Network issued in 2014. The new code has 42 Articles and is based on the principle of comply-or-explain. The following are the main changes of the updated code:

A - The code has established the following principles: transparency, acknowledgement of responsibility, justice, and equality;

B - BoD:

- Detailing the qualifications and competencies of BoD members, experience required to do their duties effectively, devote enough time to do the job, etc;

- Prohibiting combining the positions of chairman and vice-chairman in more than two companies whose headquarters are located in the state. Or being a member of the BoD of more than three shareholding companies;

- Detailing BoD functions, rights, duties and the responsibilities of the chairman and members, as well as the requirements for task delegation.;

C - The functions and responsibilities of the external auditor and the contents of his report;

D - The requirement of disclosure and transparency concerning information related to the BoD chairman, members, and committees and their qualifications;

$\mathrm{E}$ - Defining related parties and the procedures required to approve related party transactions;

$\mathrm{F}$ - The requirement to disclose securities trading by BoD members or senior executive management, all insiders, their spouses and minor children;

$\mathrm{G}$ - Shareholders' rights, which include participation and voting in GAMs;

$\mathrm{H}$ - The community's right, including the role of the company in developing and promoting the community and preserving the environment.

\subsubsection{Kuwait}

Kuwait issued its first CG code in April 2010, titled "CSR's Corporate Governance Code: Principles \& Recommended Best Practices for Public Companies", which intended to improve its ranking in international business indicators, with the ultimate objective of boosting investors' confidence in the board, management and control systems of companies, and thereby helping to attract more FDI inflows to achieve high sustained economic growth (ECGI, 2017).

In line with recent global and regional trends, a new companies law was issued in January 2016 to update corporate infrastructure in the state (Kuwait Ministry of Commerce and Industry, 2016). In addition, an updated CG code was issued in 2015 and came into force in June 2016. The new CG code is based on the comply-or-explain principle. The main changes are as follows:

A - BoD:

- The composition of the BoD, competencies of the chairman and the members of BoD. The majority of the members shall be non-executive members and independent members shall not exceed half the members of the board;

- Detailing aspects of BoD meetings, quorum, agenda, minutes of meetings, and the requirement to enable BoD members to obtain accurate and timely information; 
- Detailing the roles and responsibilities of BoD members and the executive management;

- The requirements to form specialized committees to prepare recommendations regarding candidates for the BoD and executive management, members' compensation and remuneration policies and regulations;

- The requirement to disclose the necessary information in a remunerations report;

B - The formation of an audit committee, defining its powers and responsibilities;

$\mathrm{C}$ - The requirement to appoint an independent external auditor, providing their main tasks;

D - The requirement to set up an effective internal auditor system with the main functions;

$\mathrm{E}$ - The requirement to set up an independent unit for risk management, which shall identify, measure, and monitor risks associated with the company's activities;

F - Promote code of conduct and ethical standards;

$\mathrm{G}$ - The requirement to develop policies and mechanisms to reduce conflicts of interest and to ensure timely and high-quality disclosure and transparency;

$\mathrm{H}$ - Detailing the general rights of shareholders, including encouraging shareholders to participate and vote in the company's GAMs;

I - Detailing the roles of stakeholders, including respecting and protecting the rights of stakeholders in accordance with related laws applicable in Kuwait;

$\mathrm{J}$ - The requirement to give training to $\mathrm{BoD}$ members and develop systems and mechanisms to evaluate the performance of $\mathrm{BoD}$ and executive management;

$\mathrm{K}$ - The requirement to develop a policy for corporate social responsibility (CSR) and highlight the company's efforts in the field of social work.

\subsubsection{Bahrain}

To enhance investor confidence and foster economic development, the Government of Bahrain issued its CG Code in 2010, jointly developed through a consultative process between the Ministry of Industry and Commerce (MOIC), the Central Bank of Bahrain, and the National Corporate Governance Committee. The Bahraini CG code was issued in a comply-or-explain framework and is mainly based on nine fundamental core principles, each of which is followed by one or more broad directives for applying the principle. The Bahraini CG code is applicable to all listed companies and financial institutions (MOIC, 2010).

The main contents of the Bahraini CG code are as follows:

A - The company shall be headed by an effective, collegial and informed BoD. Under this principle are various directives and recommendations, including the main board's role and responsibilities, BoD's decision-making process, BoD's representation of all shareholders, committees of BoD (audit, remuneration and nominating, and risk committees), evaluation of the BoD and each committee;

B - Members of the BoD and officers shall have full loyalty to the company, including personal accountability, avoidance of conflicts of interest and disclosure of cases of conflict of interest;

C - The BoD shall have rigorous controls for financial audit and reporting, internal control, and compliance with the law, including all issues related to audit committee formation, roles and responsibilities, qualifications of its members, and operation;

D - The requirement to have rigorous procedures for appointing, training, and evaluating BoD members, including nominating the committee and its charter in addition to their qualifications, responsibilities, and the committees' structures and operation;

E - The requirement to set up a remuneration committee in the company to ensure directors and officers are remunerated fairly and responsibly, including the qualifications, roles and responsibilities of the committee members, and the structures and operation of the committee;

F - The requirement to establish a clear and efficient management structure, which includes titles, authorities, duties and reporting responsibilities;

$\mathrm{G}$ - The requirement to communicate with shareholders, encourage their participation in shareholders' meeting, and respect their rights; 
$\mathrm{H}$ - The requirement to disclose corporate governance as required by law.

Unlike other GCC Countries in the region, there are no clear indications of plans to update the CG code of Bahrain, which was adopted in 2010.

\section{Comparative Analysis of the Recent Developments in CG Codes in the GCC Region}

\subsection{Developments Related to CG Code Infrastructure}

As illustrated in Table I, there has been a dominant regional trend during the last couple of years towards updating national CG infrastructures. All GCC states except Bahrain have recently adopted structural legislative amendments to corporate laws and have updated their CG codes with necessary details covering all common aspects of governance under the supervision of the competent financial market authority in each state. In addition, most of the GCC states have shifted from a voluntary basis towards either a comply-or-explain or a mandatory basis, which clearly indicates that the business environment is more open to applying CG and the competent authorities are serious in enforcing it. Despite the fact that the application of CG codes in all GCC states is still limited to listed public joint stock companies, these changes undoubtedly have contributed to the efforts to improve CG infrastructure in the region.

\subsection{Regional Developments Related to the Subjects Covered in CG Codes}

As illustrated in Table II, all GCC states except Bahrain have recently updated their CG code in line with recent international practice, which expressly reflects the commitment of the region to the CG field. The main changes adopted across the region in the updated codes can be summarized as follows:

A - Specific emphasis on the $\mathrm{BoD}$ as an independent decision-making body to be established in listed companies, with related requirements detailed in all updated CG codes, such as BoD composition, roles and responsibilities, structure (i.e. independent and non-executive members), BoD meetings, rights and duties of BoD members as well as the chairman, BoD members' skills and competencies, access to information, ethical duties (like the duty to disclose any conflict of interest), honesty, and transparency. These structural updates clearly show the regional trend towards establishing effective institutional frameworks for listed companies, with clear separation between shareholders and management, as well as combatting corruption and unethical behaviour and improving credibility and trust in stock markets in the region.

B - The updated CG codes of UAE, KSA, and Qatar specify requirements related to GAMs, such as invitations to shareholders, the requirements for passing special resolutions, records of the meetings, voting rights. These updates protect the rights of shareholders and assure them that appropriate processes are in place to closely supervise the operation of the company.

$\mathrm{C}$ - The basic rights of shareholders have been detailed in the updated CG codes of UAE, KSA, and Qatar, covering the most common rights, such as equality in rights and obligations; share in profits; share in the company's assets upon liquidation; the right to attend GAMs, participate in the discussions, and vote on decisions; the right to dispose of shares; the right to review the company's financial statements and reports, records, and documents. These updates show a strong regional trend towards guaranteeing the main rights of shareholders in listed stock companies, which may help attract more investors in the stock markets in the GCC region.

D - The rights of stakeholders have been newly regulated in KSA, while detailed in both Kuwait and Qatar, including the rules of relationships with stakeholders, respecting the rights of the stakeholders as stated by law, reporting non-compliant practices, and mechanisms for employees' participation. These updates reflect a strong trend in the three GCC countries towards law enforcement and building confidence and trust in the corporate environment.

E - Most of the updated CG codes in the GCC have defined related parties and how related party transactions are approved, providing requirements for data and information on the related parties and the terms and conditions of the deal.

F - Only the updated CG code of UAE has stated a requirement to appoint investors' relations officers to undertake all the duties associated with managing investor relations, detailing the qualifications of the officers. In addition, there is a new requirement to disclose all information/news, financial statements/reports to the public in an effective and timely manner. This reflects the efforts of the UAE government to build up effective relations with current investors in listed joint stock companies as well as to attract more investors, both national and foreigners, to the UAE stock market.

G - All updated CG codes have a requirement to have an independent external auditor, specifying how to appoint him and his obligations, ethical duties, and the contents of his reports. This clearly shows the regional trend towards 
reducing illegal and unethical behaviour and building up trust and confidence between listed companies and the stakeholders.

$\mathrm{H}$ - All updated CG codes in the region regulate in detail the roles and responsibilities of the internal auditors and, in KSA and Kuwait, setting up internal control systems, including the establishment of an independent unit in the company, duties of the internal audit unit, composing an internal audit unit, plans, and reports. This reflects the regional trend towards emphasising internal auditing to combat illegal and unethical behaviour in listed companies and enhancing trust and confidence in the stock market.

I - All updated CG codes have detailed the establishment of permanent committees (remuneration, nomination and auditing committees) to assist and advise the $\mathrm{BoD}$, specifying roles and responsibilities, members' competencies and the structure for each committee. It is a clear regional trend to enhance the institutional framework of BoD by providing all the necessary capabilities and professions to act effectively and professionally.

J - All updated CG codes have a requirement to submit CG reports with specific contents to be provided, including CG principles applied and the plans to implement CG requirements. This regional trend reflects the strong commitment of listed companies in the region to implementing CG and the necessary transparency for shareholders and public about compensation and allowances for the chairman and members of the $\mathrm{BoD}$ and its sub-committees, as well as directors at management level.

$\mathrm{K}$ - Only the updated CG code of the UAE requires the appointment of a compliance officer, to oversee the company and its employees, ensure compliance with the law, regulations and resolutions issued, as well as the company's articles of association and resolutions of GAMs of the BoD.

L - The updated CG codes of KSA, Kuwait, and Oman require the development of professional codes of conduct and ethical standards, including establishing a policy for professional conduct and ethical values at the company, social responsibility, and social initiatives. This regional trend also shows the commitment of listed companies to adopt and apply professional conduct and values.

M - The updated CG codes of Kuwait, Oman, and Qatar require the development of a policy to promote CSR and highlight companies' efforts in the field of social work, to ensure a balance between the company's goals and society's goals. This regional trend illustrates the efforts of governments to enhance the role of the private sector in handling social responsibility in the community.

\section{Current CG Codes of GCC States Compared With the G20/OECD Principles of Corporate Governance, 2015 Edition}

As the G20/OECD Principles have become the updated benchmark for many countries worldwide, a brief comparison has been made to define to what extent the current CG codes in the GCC region are really in line with the updated CG principles adopted by G20/OECD, 2015 Edition. As stated in Tables III-VII, the results are as follows:

4.1 The Basis for an Effective CG Framework in GCC States, According to the Requirements of Chapter I of the G20/OECD Principles

As illustrated in Table III, the whole basis for an effective CG framework in GCC states, according to the requirements of Chapter I of the G20/OECD Principles, is met except for the requirement for cross-border co-operation, through bilateral, regional and multilateral arrangements, to exchange information. However, such regional cooperation can be developed under the GCC Unified Economic Agreement.

4.2 Shareholders' Rights and Key Ownership Functions in CG Codes in GCC States, According to the Requirements of Chapter II of the G20/OECD Principles

Table IV shows that the CG codes in all GCC states except Bahrain have regulated the basic rights of shareholders in listed companies, including the right to be informed about any change in the legal status of the company, voting in GAMs, equal treatment, and related party transactions. The rights of shareholders relating to mergers and acquisitions are not covered in the CG codes, as they are mainly regulated by corporate law.

4.3 Institutional Investors, Stock Markets, and Other Intermediaries in CG Codes in GCC States, According to the Requirements of Chapter III of the G20/OECD Principles

Since CG codes in all GCC states only apply to listed companies, institutional investors like State-Owned Enterprises (SOEs), pension funds, and Sovereign Wealth Funds (SWFs) are not subject to the CG codes. Therefore, the 
requirements related to institutional investors, covered under Chapter III of G20/OECD of 2015, have not been met in any CG code in a GCC state.

4.4 Disclosure and Transparency in CG Codes in GCC States, According to the Requirements of Chapter V of the G20/OECD Principles

As shown in Table VI, all CG codes in GCC states require disclosure and transparency of specific information and data with high-quality standards, including financial information, shares ownership structure, remuneration of BoD members and key executives, related party transactions, governance structure and policies. In addition, the codes require an annual audit report which should be conducted by an independent, competent and qualified auditor. Finally, the channels for disseminating the information should provide equal, timely and cost-efficient access to relevant information by users.

4.5 The Role of Stakeholders in CG Codes in GCC States, According to the Requirements of Chapter IV of the G20/OECD Principles

As illustrated in Table V, only the CG codes of KSA, Kuwait, and Qatar provided regulations to respect stakeholders' rights, giving them the right to obtain effective redress for violations, setting up a mechanism for employees' participation in BoD meetings, giving them access to the company's information on a timely and regular basis, and the right of whistleblowing. In contrast, other GCC states do not regulate stakeholders' rights in their CG codes, leaving these issues to the general laws and regulations. However, no CG codes in the region protect the rights of the stakeholders in case of insolvency, leaving such issues to be regulated by the general laws.

4.6 The Responsibilities of BoD in CG Codes in GCC States, According to the Requirements of Chapter VI of the G20/OECD Principles

As illustrated in Table VII, all the CG codes in GCC states have regulated in detail the responsibilities and the ethical duties of BoD members, with the necessary access to accurate and timely information, structure of the board (independent and non-executive members), key functions of the $\mathrm{BoD}$, and setting up specialized committees (audit, remuneration, nomination, and risk management) with their mandates.

\section{Conclusion}

The update of CG codes has progressed dramatically in the GCC region since 2014 and many countries have shifted from a voluntary basis to either a comply-or-explain or a mandatory basis, which reflects the maturity of the business environment that is committed to such international practices. Furthermore, the recent structural legislative amendments in corporate laws in the GCC region have also contributed to integrating the efforts to improve corporate governance infrastructure in the region. Considering the importance of enhancing trust and confidence of the investors in listed companies, in order to attract foreign and local investors to the stock markets of the GCC region, the regional developments in the CG codes have mainly concentrated on adopting new requirements or expanding the existing requirements to improve the independent role and functions of the $\mathrm{BoD}$ and its committees, transparency and the disclosure of related party transactions, the role of external and internal auditors, and professional practices. Although corporate legislation in GCC states stipulates the basic rights of the shareholders, these rights have been detailed in the updated CG codes to guarantee shareholders direct and easy access to their rights.

The recent developments in CG codes in the GCC region bring these codes into line with international best practice, as summarized in G20/OECD of 2015, except for the third principle related to institutional investors. However, Bahrain needs to update its old CG code of 2010 to be in line with recent developments worldwide. These intensive efforts to enhance CG in listed companies should be continued and expanded to cover SOEs, pension funds, SWFs, and banks, as well as empowering financial institutions to combat corruption and amy other unethical behaviour, and to achieve the overall objective of building up a sustainable and attractive business environment.

The results of the study will be of great benefit to the GCC economies. Such structural updates clearly show the regional trend towards establishing effective institutional frameworks for listed companies, with a clear separation between shareholders and management, as well as combatting corruption and unethical behaviour and improving credibility and trust in stock markets in the region.

The main challenge in the GCC region is not only to adopt CG codes according to international best practice but also to implement CG principles by enabling a specialized authority with an effective, transparent and fully explained supervisory role, which must have the necessary technical resources to fulfil its duties in a professional and objective manner. 
Table 1. Current CG infrastructure

\begin{tabular}{|c|c|c|c|c|c|c|}
\hline Item & UAE & KSA & Kuwait & Bahrain & Oman & Qatar \\
\hline $\begin{array}{ll}\text { New } & \text { Companies } \\
\text { Law } & \end{array}$ & $\begin{array}{l}\text { Federal } \\
\text { Commercial } \\
\text { Companies Law } \\
\text { No. } 2 \text { of } 2015 \\
\end{array}$ & $\begin{array}{l}\text { Royal Decree } \\
\text { No. } 3 \text { of } 2015 \\
\text { for Companies } \\
\text { Law. }\end{array}$ & $\begin{array}{l}\text { Company Law No. } 1 \\
\text { of } 2016\end{array}$ & $\begin{array}{l}\text { Amendments to } \\
\text { Company law, Law No. } \\
50 \text { of } 2014\end{array}$ & $\begin{array}{l}\text { Commercial } \\
\text { Companies Law No. } 4 \\
\text { of } 1974\end{array}$ & $\begin{array}{l}\text { Companies Law No. } \\
11 \text { of } 2015\end{array}$ \\
\hline Name of CG Code & $\begin{array}{l}\text { The Standards } \\
\text { of Institutional } \\
\text { Discipline and } \\
\text { Governance of } \\
\text { Public } \\
\text { Shareholding } \\
\text { Companies }\end{array}$ & $\begin{array}{l}\text { Corporate } \\
\text { Governance } \\
\text { Code }\end{array}$ & Corporate Governance & $\begin{array}{l}\text { Corporate Governance } \\
\text { Code }\end{array}$ & $\begin{array}{lr}\text { Code of } & \text { Corporate } \\
\text { Governance for } \\
\text { Publicly Held Joint } \\
\text { Stock Companies }\end{array}$ & $\begin{array}{l}\text { Corporate Governance } \\
\text { Code for Companies } \\
\text { and Legal Entities } \\
\text { Listed on the Main } \\
\text { Market, }\end{array}$ \\
\hline $\begin{array}{l}\text { Scope of } \\
\text { Application }\end{array}$ & $\begin{array}{l}\text { Public Joint } \\
\text { Stock } \\
\text { Companies } \\
\text { Listed on Stock } \\
\text { Market } \\
\end{array}$ & $\begin{array}{l}\text { Public Joint } \\
\text { Stock } \\
\text { Companies } \\
\text { Listed on Stock } \\
\text { Market }\end{array}$ & $\begin{array}{l}\text { Public Joint Stock } \\
\text { Companies Listed on } \\
\text { Stock Market }\end{array}$ & $\begin{array}{l}\text { Public Joint Stock } \\
\text { Companies Listed on } \\
\text { Stock Market and } \\
\text { Financial Institutions }\end{array}$ & $\begin{array}{l}\text { Public Joint Stock } \\
\text { Companies Listed on } \\
\text { Stock Market }\end{array}$ & $\begin{array}{l}\text { Public Joint Stock } \\
\text { Companies Listed on } \\
\text { Stock Market }\end{array}$ \\
\hline $\begin{array}{l}\text { Nature of the } \\
\text { Code }\end{array}$ & $\begin{array}{l}\text { Consists of } 55 \\
\text { articles } \\
\text { distributed in } \\
\text { three chapters. }\end{array}$ & $\begin{array}{l}\text { Consists of } 98 \\
\text { articles } \\
\text { distributed in } 12 \\
\text { chapters. }\end{array}$ & $\begin{array}{l}\text { Based on } 11 \text { general } \\
\text { principles. }\end{array}$ & $\begin{array}{l}\text { Based on nine } \\
\text { fundamental principles. }\end{array}$ & $\begin{array}{l}\text { Based on } 14 \text { principles } \\
\text { with three annexes. }\end{array}$ & $\begin{array}{l}\text { Consists of } 42 \text { Articles } \\
\text { distributed in seven } \\
\text { chapters. }\end{array}$ \\
\hline $\begin{array}{l}\text { Mechanism by } \\
\text { which CG Code } \\
\text { Issued }\end{array}$ & $\begin{array}{l}\text { SCA's } \\
\text { Resolution No. } \\
7 \text { R.M of } 2016\end{array}$ & $\begin{array}{l}\text { Capital Market } \\
\text { Authority } \\
\text { Resolution } \\
\text { No .8-6-2017 of } \\
2017\end{array}$ & $\begin{array}{l}\text { Executive Regulations } \\
\text { of } 2015\end{array}$ & $\begin{array}{l}\text { Executive Regulation } \\
\text { of } 2010\end{array}$ & $\begin{array}{l}\text { CMA CG Code, July } \\
2015\end{array}$ & $\begin{array}{l}\text { QFMA Chairman No. } \\
5 \text { of } 2016\end{array}$ \\
\hline $\begin{array}{l}\text { Date CG Code } \\
\text { Issued }\end{array}$ & April 2016 & February 2017 & June 2015 & 2010 & July 2015 & November 2016 \\
\hline $\begin{array}{l}\text { Enforcement Date } \\
\text { of CG Code }\end{array}$ & April 2016 & $\begin{array}{lr}\text { February } & 2017, \\
\text { except some } \\
\text { provisions in } \\
\text { December } & 2017 \\
\end{array}$ & June 2016 & 2010 & July 2016 & November 2016 \\
\hline $\begin{array}{l}\text { Supervisory } \\
\text { Authority of CG } \\
\text { Code }\end{array}$ & $\begin{array}{l}\text { Securities and } \\
\text { Commodities } \\
\text { Authority } \\
\text { (SCA) }\end{array}$ & $\begin{array}{l}\text { Capital Market } \\
\text { Authority } \\
\text { (CMA) }\end{array}$ & $\begin{array}{l}\text { Capital } \\
\text { Authority }\end{array}$ & $\begin{array}{l}\text { National Corporate } \\
\text { Governance Committee } \\
\text { in Cooperation with } \\
\text { Ministry of Industry \& } \\
\text { Commerce and Central } \\
\text { Bank. }\end{array}$ & $\begin{array}{l}\text { Capital } \\
\text { Authority }\end{array}$ & $\begin{array}{ll}\text { Qatar } & \text { Financial } \\
\text { Market } & \text { Authority } \\
\text { (QFMA) } & \end{array}$ \\
\hline Basis of CG Code & Mandatory & Mandatory & $\begin{array}{l}\text { Changed to two parts: } \\
\text { mandatory and } \\
\text { comply-or-explain }\end{array}$ & Comply-or-explain & Comply-or-explain & $\begin{array}{l}\text { Changed } \\
\text { comply-or-explain }\end{array}$ \\
\hline
\end{tabular}


Table 2. Regional developments in CG codes except Bahrain

\begin{tabular}{|c|c|c|c|c|c|}
\hline Item & UAE (2016) & KSA (2017) & Kuwait (2015) & Oman (2015) & Qatar (2016) \\
\hline $\begin{array}{l}\text { BoD composition, roles and } \\
\text { responsibilities, } \\
\text { meetings, rights and duties of BoD, } \\
\text { members' skills and competencies } \\
\text { of BoD members and the } \\
\text { chairman, access to information, } \\
\text { ethical duties, etc. }\end{array}$ & $\begin{array}{l}\text { Detailed, } \\
\text { one third } \\
\text { must be } \\
\text { independent } \\
\text { and the } \\
\text { majority } \\
\text { non-executive } \\
20 \% \text { female }\end{array}$ & $\begin{array}{l}\text { Detailed, } \\
\text { one third must be } \\
\text { independent and the } \\
\text { majority non-executive }\end{array}$ & $\begin{array}{l}\text { Detailed, } \\
\text { no less than half } \\
\text { must be } \\
\text { independent and } \\
\text { the majority } \\
\text { non-executive }\end{array}$ & $\begin{array}{l}\text { Detailed, } \\
\text { one third must be independent } \\
\text { and the all non-executive }\end{array}$ & $\begin{array}{l}\text { Detailed, } \\
\text { one third must be } \\
\text { independent and the } \\
\text { majority } \\
\text { non-executive }\end{array}$ \\
\hline 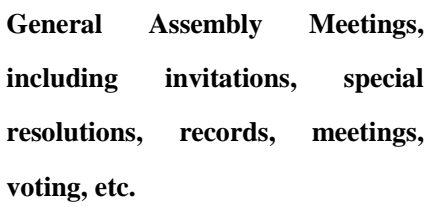 & $\begin{array}{l}\text { Newly } \\
\text { regulated in } \\
\text { detail }\end{array}$ & Detailed & Provided & Not regulated & Detailed \\
\hline Shareholders' basic rights & Detailed & Detailed & Provided & Not regulated & Detailed \\
\hline $\begin{array}{l}\text { Stakeholders rights, including the } \\
\text { rules of the relationship with } \\
\text { stakeholders, reporting } \\
\text { non-compliant practices, employee } \\
\text { incentives }\end{array}$ & Not regulated & Newly regulated & Detailed & Not regulated & Detailed \\
\hline Related party transactions & $\begin{array}{l}\text { Detailed } \\
\text { under } \\
\text { disclosure \& } \\
\text { transparency } \\
\text { duty }\end{array}$ & $\begin{array}{l}\text { Detailed under } \\
\text { disclosure \& } \\
\text { transparency duty }\end{array}$ & $\begin{array}{l}\text { Detailed under } \\
\text { disclosure \& } \\
\text { transparency duty }\end{array}$ & Newly regulated & $\begin{array}{l}\text { Detailed under the } \\
\text { disclosure \& } \\
\text { transparency duty }\end{array}$ \\
\hline $\begin{array}{l}\text { Investors' relations for } \\
\text { information disclosure for public }\end{array}$ & $\begin{array}{l}\text { Newly } \\
\text { regulated }\end{array}$ & Not regulated & Not regulated & Not regulated & Not regulated \\
\hline External auditor & Detailed & Newly regulated & Detailed & Provided & Detailed \\
\hline Internal auditor/control & Detailed & Newly regulated & Detailed & Provided & Detailed \\
\hline $\begin{array}{l}\text { Setting up permanent committees: } \\
\text { audit, remuneration, nomination } \\
\text { committees and their roles }\end{array}$ & Detailed & Detailed & Detailed & Provided & Detailed \\
\hline $\begin{array}{l}\text { CG Report/or requirements } \\
\text { including implementation of } \\
\text { effective CG }\end{array}$ & Detailed & Newly regulated & Newly regulated & Detailed & Newly Regulated \\
\hline Compliance officer & $\begin{array}{l}\text { Newly } \\
\text { regulated }\end{array}$ & Not regulated & Not regulated & Not regulated & Not regulated \\
\hline Professional conduct code & Not regulated & Newly regulated & Newly regulated & Newly regulated & Not regulated \\
\hline Corporate social responsibility & Not regulated & Not regulated & Newly regulated & Newly regulated & Newly regulated \\
\hline
\end{tabular}


Table 3. The basis for an effective CG framework in the GCC region, according to Chapter I of G20/OECD Principles

\begin{tabular}{|c|c|c|c|c|c|c|}
\hline Item & UAE & KSA & Kuwait & Bahrain & Oman & Qatar \\
\hline $\begin{array}{l}\text { CG framework } \\
\text { should be } \\
\text { developed with a } \\
\text { view to its impact } \\
\text { on overall } \\
\text { economic } \\
\text { performance }\end{array}$ & $\begin{array}{l}\text { CG infrastructure } \\
\text { gradually } \\
\text { established, } \\
\text { starting in } 2004 \\
\text { and the first code } \\
\text { was in } 2009 \text {. } \\
\text { Updated CG code } \\
\text { issued in } 2016\end{array}$ & $\begin{array}{l}\text { CG infrastructure } \\
\text { gradually } \\
\text { established by } \\
\text { first code in } 2006 \\
\text { and updated CG } \\
\text { code issued in } \\
2017\end{array}$ & $\begin{array}{l}\text { CG infrastructure gradually } \\
\text { established, starting with first } \\
\text { CG code in 2010, updated CG } \\
\text { code issued in } 2016\end{array}$ & $\begin{array}{l}\text { CG code issued } \\
\text { in } \\
2010\end{array}$ & $\begin{array}{l}\text { CG infrastructure } \\
\text { gradually established, } \\
\text { starting with first code } \\
\text { in 2002; updated CG } \\
\text { code issued on } 2015\end{array}$ & $\begin{array}{l}\text { CG } \\
\text { infrastructure } \\
\text { gradually } \\
\text { established by } \\
\text { the first CG } \\
\text { code in } 2009 \\
\text { and the } \\
\text { updated CG } \\
\text { Code issued in } \\
2015\end{array}$ \\
\hline $\begin{array}{l}\text { The legal and } \\
\text { regulatory } \\
\text { requirements } \\
\text { should be } \\
\text { consistent with the } \\
\text { rule of law. }\end{array}$ & $\begin{array}{l}\text { Federal } \\
\text { Commercial } \\
\text { Companies Law } \\
\text { No. } 2 \text { of } 2015\end{array}$ & $\begin{array}{l}\text { Royal Decree No. } \\
3 \text { of } 2015 \text { for } \\
\text { Companies Law. } \\
\text { Capital Market } \\
\text { Authority } \\
\text { Resolution } \\
\text { No .8-6-2017 of } \\
2017\end{array}$ & $\begin{array}{l}\text { Executive Regulations of } \\
2015\end{array}$ & $\begin{array}{l}\text { Amendments to } \\
\text { Company law, } \\
\text { Law No. } 50 \text { of } \\
2014 \\
\text { Executive } \\
\text { Regulation of } \\
2010\end{array}$ & $\begin{array}{l}\text { Commercial Companies } \\
\text { Law No. } 4 \text { of } 1974 \\
\text { MA CG Code, July } \\
2015\end{array}$ & $\begin{array}{l}\text { Companies } \\
\text { Law No. } 11 \text { of } \\
2015\end{array}$ \\
\hline $\begin{array}{l}\text { The division of } \\
\text { responsibilities. } \\
\text { Stock market } \\
\text { regulation should } \\
\text { support effective } \\
\text { CG. } \\
\text { Supervisory, } \\
\text { regulatory } \\
\text { authority }\end{array}$ & $\begin{array}{l}\text { SCA has full } \\
\text { authority to } \\
\text { regulate market } \\
\text { and monitor } \\
\text { implementation of } \\
\text { CG }\end{array}$ & $\begin{array}{l}\text { CMA has full } \\
\text { authority to } \\
\text { regulate market } \\
\text { and monitor } \\
\text { implementation of } \\
\text { CG }\end{array}$ & $\begin{array}{l}\text { CMA has full authority to } \\
\text { regulate market and monitor } \\
\text { implementation of CG }\end{array}$ & $\begin{array}{l}\text { No specialized } \\
\text { market authority } \\
\text { has been } \\
\text { established }\end{array}$ & $\begin{array}{l}\text { CMA has full authority } \\
\text { to regulate market and } \\
\text { monitor implementation } \\
\text { of CG }\end{array}$ & $\begin{array}{l}\text { QFMA has full } \\
\text { authority to } \\
\text { regulate market } \\
\text { and monitor } \\
\text { implementation } \\
\text { of CG }\end{array}$ \\
\hline $\begin{array}{l}\text { Cross-border } \\
\text { co-operation } \\
\text { should be } \\
\text { enhanced, }\end{array}$ & $\begin{array}{l}\text { It is not regulated } \\
\text { by the code, but it } \\
\text { can be covered by } \\
\text { GCC Unified }\end{array}$ & $\begin{array}{l}\text { It is not regulated } \\
\text { by the code, but it } \\
\text { can be covered by } \\
\text { GCC Unified }\end{array}$ & $\begin{array}{l}\text { It is not regulated by the code, } \\
\text { but it can be covered by GCC } \\
\text { Unified Economic Agreement }\end{array}$ & $\begin{array}{l}\text { It is not regulated } \\
\text { by the code, but it } \\
\text { can be covered by } \\
\text { GCC Unified }\end{array}$ & $\begin{array}{l}\text { It is not regulated by the } \\
\text { code, but it can be } \\
\text { covered by GCC } \\
\text { Unified Economic }\end{array}$ & $\begin{array}{l}\text { It is not } \\
\text { regulated by } \\
\text { the code, but it } \\
\text { can be covered }\end{array}$ \\
\hline including through & Economic & Economic & & Economic & Agreement & GCC \\
\hline $\begin{array}{lr}\text { bilateral } & \text { and } \\
\text { multilateral } & \\
\text { arrangements } & \text { for } \\
\text { exchange } & \text { of } \\
\text { information } & \end{array}$ & Agreement & Agreement & & Agreement & & $\begin{array}{l}\text { Unified } \\
\text { Economic } \\
\text { Agreement }\end{array}$ \\
\hline
\end{tabular}


Table 4. Shareholders' rights in CG Codes in the GCC region in comparison with the guidelines of Chapter II of G20/OECD Principles




Table 5. The Role of stakeholders in CG codes in the GCC region in comparison with the guidelines of Chapter IV of G20/OECD Principles

\begin{tabular}{|c|c|c|c|c|c|c|}
\hline Item & UAE (2016) & KSA (2017) & Kuwait (2015) & Bahrain (2010) & Oman (2015) & Qatar (2016) \\
\hline $\begin{array}{l}\text { Respecting the rights of } \\
\text { stakeholders as stated by law }\end{array}$ & Not regulated & $\begin{array}{l}\text { Regulated in } \\
\text { detail by Article } \\
83\end{array}$ & $\begin{array}{l}\text { Regulated in } \\
\text { detail by Chapter } \\
10\end{array}$ & Not regulated & Not regulated & $\begin{array}{l}\text { Regulated in } \\
\text { general by Article } \\
38\end{array}$ \\
\hline $\begin{array}{l}\text { Stakeholders' rights to obtain } \\
\text { effective redress for violation }\end{array}$ & Not regulated & $\begin{array}{l}\text { Regulated in } \\
\text { detail by Article } \\
83\end{array}$ & $\begin{array}{l}\text { Regulated in } \\
\text { detail by Chapter } \\
10\end{array}$ & Not regulated & Not regulated & $\begin{array}{l}\text { Regulated in } \\
\text { general by Article } \\
38\end{array}$ \\
\hline $\begin{array}{l}\text { Mechanisms for employees' } \\
\text { participation }\end{array}$ & Not regulated & $\begin{array}{l}\text { Regulated in } \\
\text { detail by Article } \\
85\end{array}$ & $\begin{array}{l}\text { Stated in Chapter } \\
12 \text { as part of CSR }\end{array}$ & Not regulated & Not regulated & Not regulated \\
\hline $\begin{array}{l}\text { Stakeholders should have } \\
\text { access to company's } \\
\text { information on timely and } \\
\text { regular basis }\end{array}$ & Not regulated & $\begin{array}{l}\text { Regulated in } \\
\text { detail by Article } \\
83\end{array}$ & $\begin{array}{l}\text { Regulated in } \\
\text { detail by Chapter } \\
10\end{array}$ & Not regulated & Not regulated & $\begin{array}{l}\text { Regulated in } \\
\text { general by Article } \\
38\end{array}$ \\
\hline $\begin{array}{l}\text { Stakeholders' right to whistle } \\
\text { blowing }\end{array}$ & Not regulated & $\begin{array}{l}\text { Regulated in } \\
\text { detail by Article } \\
84\end{array}$ & $\begin{array}{l}\text { Regulated in } \\
\text { detail by Chapter } \\
10\end{array}$ & Not regulated & Not regulated & $\begin{array}{l}\text { Regulated in } \\
\text { general by Article } \\
38\end{array}$ \\
\hline $\begin{array}{l}\text { Efficient } \\
\text { framework }\end{array}$ & $\begin{array}{l}\text { Not regulated } \\
\text { (general } \\
\text { insolvency and } \\
\text { bankruptcy laws } \\
\text { are applicable), a } \\
\text { new bankruptcy } \\
\text { law has been } \\
\text { recently issued. }\end{array}$ & $\begin{array}{l}\text { Not regulated } \\
\text { (general } \\
\text { insolvency and } \\
\text { bankruptcy laws } \\
\text { are applicable), a } \\
\text { new bankruptcy } \\
\text { law has been } \\
\text { recently drafted. }\end{array}$ & $\begin{array}{l}\text { Not regulated } \\
\text { (general } \\
\text { insolvency and } \\
\text { bankruptcy laws } \\
\text { are applicable), a } \\
\text { new bankruptcy } \\
\text { law has been } \\
\text { recently drafted. }\end{array}$ & $\begin{array}{l}\text { Not regulated } \\
\text { (general } \\
\text { insolvency and } \\
\text { bankruptcy laws } \\
\text { are applicable) }\end{array}$ & $\begin{array}{l}\text { Not regulated } \\
\text { (general } \\
\text { insolvency and } \\
\text { bankruptcy laws } \\
\text { are applicable) }\end{array}$ & $\begin{array}{l}\text { Not regulated } \\
\text { (general insolvency } \\
\text { and bankruptcy } \\
\text { laws are applicable) }\end{array}$ \\
\hline
\end{tabular}


Table 6. Disclosure and transparency in CG codes in the GCC region in comparison with the guidelines of Chapter V of G20/OECD Principles

\begin{tabular}{|c|c|c|c|c|c|c|}
\hline Item & UAE (2016) & KSA (2017) & Kuwait (2015) & Bahrain (2010) & Oman (2015) & Qatar (2016) \\
\hline $\begin{array}{l}\text { Disclosure should include financial and } \\
\text { non-financial data, shares' ownership } \\
\text { structure, information about } \\
\text { qualifications, selection process, } \\
\text { remuneration of BoD and key } \\
\text { executives, related party transactions, } \\
\text { foreseeable risk factors, governance } \\
\text { structure and policies }\end{array}$ & $\begin{array}{l}\text { Regulated in } \\
\text { detail by Article } \\
35\end{array}$ & $\begin{array}{l}\text { Regulated in } \\
\text { detail by } \\
\text { Chapter } 9 \\
\text { (Articles } 89 \\
\text { to 93) }\end{array}$ & $\begin{array}{l}\text { Regulated in detail } \\
\text { by Chapter } 8\end{array}$ & $\begin{array}{l}\text { Regulated in } \\
\text { detail under } \\
\text { Appendix E } \\
\text { (Corporate } \\
\text { Governance } \\
\text { Disclosure) }\end{array}$ & $\begin{array}{l}\text { Regulated in } \\
\text { detail under } \\
\text { Annexure No. } 3 \\
\text { (Items to be } \\
\text { covered in the } \\
\text { report on } \\
\text { corporate } \\
\text { governance) }\end{array}$ & $\begin{array}{l}\text { Regulated } \\
\text { detail } \\
\text { Article } 25 \\
\text { Chapter V }\end{array}$ \\
\hline $\begin{array}{l}\text { Information disclosed in accordance } \\
\text { with high quality } \\
\text { accounting } \\
\text { reporting }\end{array}$ & $\begin{array}{l}\text { Regulated in } \\
\text { detail by Article } \\
35\end{array}$ & $\begin{array}{l}\text { Regulated in } \\
\text { detail by } \\
\text { Article } 89\end{array}$ & $\begin{array}{l}\text { Regulated in detail } \\
\text { by Chapter } 8\end{array}$ & $\begin{array}{l}\text { Regulated in } \\
\text { detail under } \\
\text { Appendix E } \\
\text { (Corporate } \\
\text { Governance } \\
\text { Disclosure) }\end{array}$ & $\begin{array}{l}\text { Generally } \\
\text { covered under } \\
\text { Principle } 2\end{array}$ & $\begin{array}{l}\text { Regulated in } \\
\text { detail by } \\
\text { Articles } 24 \text { and } \\
25\end{array}$ \\
\hline $\begin{array}{l}\text { Annual audit should be conducted by } \\
\text { an independent, competent and } \\
\text { qualified auditor }\end{array}$ & $\begin{array}{l}\text { Regulated in } \\
\text { detail by Article } \\
36\end{array}$ & $\begin{array}{l}\text { Regulated in } \\
\text { detail by } \\
\text { Chapter } 6\end{array}$ & $\begin{array}{l}\text { Regulated in detail } \\
\text { by Chapter } 5\end{array}$ & $\begin{array}{l}\text { Generally } \\
\text { regulated under } \\
\text { Principle } 3 \text { and } \\
\text { Appendix B }\end{array}$ & $\begin{array}{l}\text { Regulated in } \\
\text { detail under } \\
\text { Principle } 12\end{array}$ & $\begin{array}{l}\text { Generally } \\
\text { regulated by } \\
\text { Articles } 23 \text { and } \\
24\end{array}$ \\
\hline $\begin{array}{l}\text { External auditors should be } \\
\text { accountable to the shareholders and } \\
\text { owe duty to the company }\end{array}$ & $\begin{array}{l}\text { Regulated in } \\
\text { detail by Articles } \\
36 \text { to } 38\end{array}$ & $\begin{array}{l}\text { Regulated in } \\
\text { detail by } \\
\text { Chapter } 6\end{array}$ & $\begin{array}{l}\text { Regulated in detail } \\
\text { by Chapter } 5\end{array}$ & $\begin{array}{l}\text { Generally } \\
\text { regulated under } \\
\text { Principle } 3 \text { and } \\
\text { Appendix B }\end{array}$ & $\begin{array}{l}\text { Regulated in } \\
\text { detail under } \\
\text { Principle } 12\end{array}$ & $\begin{array}{l}\text { Generally } \\
\text { regulated by } \\
\text { Articles } 23 \text { and } \\
24\end{array}$ \\
\hline $\begin{array}{l}\text { Channels for disseminating } \\
\text { information should allow equal, timely } \\
\text { and cost-efficient access to relevant } \\
\text { information by } \\
\text { users }\end{array}$ & $\begin{array}{l}\text { Regulated in } \\
\text { detail by Article } \\
35\end{array}$ & $\begin{array}{l}\text { Regulated in } \\
\begin{array}{l}\text { detail by } \\
\text { Chapter }\end{array} \\
\text { (Articles } 93 \\
\text { to } 98 \text { ) }\end{array}$ & $\begin{array}{l}\text { Regulated in detail } \\
\text { by Chapter } 8\end{array}$ & $\begin{array}{l}\text { Regulated in } \\
\text { detail by } \\
\text { Appendix E }\end{array}$ & $\begin{array}{l}\text { Regulated in } \\
\text { detail under } \\
\text { Annexure No. } 3\end{array}$ & $\begin{array}{l}\text { Generally } \\
\text { regulated } \\
\text { Article } 25\end{array}$ \\
\hline
\end{tabular}


Table 7. Responsibilities of the BoD in CG Codes in GCC Region in comparison with the guidelines of Chapter VI of G20/OECD

\begin{tabular}{|c|c|c|c|c|c|c|}
\hline Item & UAE (2016) & KSA (2017) & Kuwait (2015) & Bahrain (2010) & Oman (2015) & Qatar (2016) \\
\hline $\begin{array}{l}\text { BoD should act on a fully } \\
\text { informed basis, in good faith, } \\
\text { with due diligence and due care, } \\
\text { to the interest of the company }\end{array}$ & $\begin{array}{l}\text { Regulated by Articles } 11 \\
\text { and } 43\end{array}$ & $\begin{array}{l}\text { Regulated by Articles } \\
20,27 \text { and } 29\end{array}$ & $\begin{array}{l}\text { Regulated } \\
\text { Chapter } 2\end{array}$ & $\begin{array}{l}\text { Regulated by } \\
\text { Principles } 1 \text { and } 2\end{array}$ & $\begin{array}{l}\text { Regulated by } \\
\text { Principles } 2 \\
\text { and } 3\end{array}$ & $\begin{array}{l}\text { Regulated } \\
\text { Article } 8\end{array}$ \\
\hline $\begin{array}{l}\text { BoD should treat all } \\
\text { stakeholders equally }\end{array}$ & egulated by Article 43 & $\begin{array}{l}\text { Regulated by Article } \\
22\end{array}$ & $\begin{array}{l}\text { Regulated by } \\
\text { Chapter } 2\end{array}$ & $\begin{array}{l}\text { Regulated by } \\
\text { Principles } 1 \& 2\end{array}$ & $\begin{array}{l}\text { Regulated } \\
\text { under } \\
\text { Principle 2 }\end{array}$ & $\begin{array}{l}\text { Regulated } \\
\text { Article } 8\end{array}$ \\
\hline $\begin{array}{l}\text { BoD should apply high ethical } \\
\text { standards regarding the interests } \\
\text { of shareholders }\end{array}$ & egulated by Article 43 & $\begin{array}{l}\text { Regulated by Article } \\
22\end{array}$ & $\begin{array}{l}\text { Regulated } \\
\text { Chapter } 3\end{array}$ & $\begin{array}{l}\text { Regulated by } \\
\text { Principles } 1 \& 2\end{array}$ & $\begin{array}{l}\text { Regulated } \\
\text { under } \\
\text { Principle } 7\end{array}$ & $\begin{array}{l}\text { Regulated } \\
\text { Article } 8\end{array}$ \\
\hline 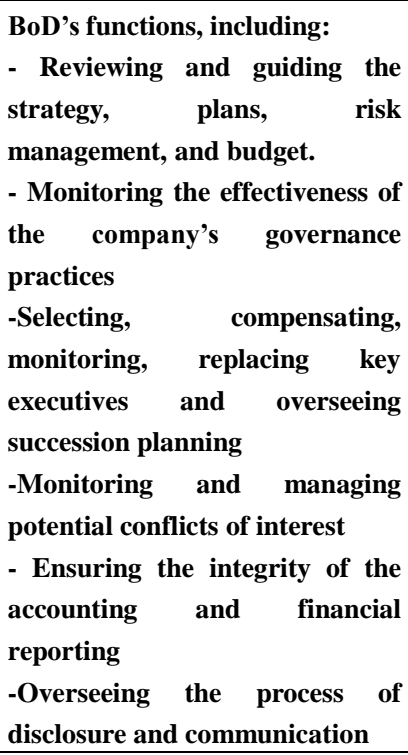 & $\begin{array}{l}\text { Regulated by Article } 43 \\
\text { Internal Control and } \\
\text { Corporate Governance } \\
\text { Report Articles } 50 \text { to } 52\end{array}$ & $\begin{array}{l}\text { Regulated by Article } \\
22 \\
\text { Chapter 6, regulating } \\
\text { conflict of interests }\end{array}$ & $\begin{array}{l}\text { Regulated } \\
\text { Chapter } 3\end{array}$ & $\begin{array}{l}\text { Regulated under } \\
\text { Principles } 1 \& 2 \\
\text { Principle } 3: \text { The } \\
\text { Board shall have } \\
\text { rigorous control } \\
\text { of financial audit } \\
\text { and reporting } \\
\text { internal control } \\
\text { and compliance } \\
\text { with the law }\end{array}$ & $\begin{array}{l}\text { Regulated } \\
\text { under } \\
\text { Principles } \\
\text { and } 3\end{array}$ & $\begin{array}{l}\text { Regulated by } \\
\text { Articles } 8 \text { and } 9 \\
\text { Article } \\
\text { Nomination } \\
\text { Committee } \\
\text { Remuneration } \\
\text { Committee an } \\
\text { Audit Committee }\end{array}$ \\
\hline $\begin{array}{l}\text {-Exercising objective } \\
\text { independent judgement on } \\
\text { corporate affairs } \\
\text {-Efficient number of } \\
\text { non-executives } \\
\text {-Setting up specialized } \\
\text { committees risk } \\
\text { management, remuneration) } \\
\text { with full mandate, and other } \\
\text { details themselves } \\
\text {-Committing their } \\
\text { effectively to } \\
\text { responsibilities } \\
\text {-Carrying out appraise the } \\
\text { evaluations to and } \\
\text { board performance }\end{array}$ & $\begin{array}{l}\text { Regulated by Articles } \\
43 \text { to } 45 \text {; one third of } \\
\text { the members must be } \\
\text { independent and the } \\
\text { majority must be } \\
\text { non-executive. } \\
\text { Permanent Committees } \\
\text { Articles } 46 \text { to } 49\end{array}$ & $\begin{array}{l}\text { Regulated by Articles } \\
16 \text { and } 20 \text {; one third } \\
\text { must be independent } \\
\text { and the majority must } \\
\text { be non-executive. } \\
\text { Chapter } 4 \text { : } \\
\text { Nominations, audit, } \\
\text { remuneration, risk } \\
\text { management }\end{array}$ & $\begin{array}{l}\text { Regulated by } \\
\text { Chapter 3 3-1 to } \\
\text { 3-6 Setting up } \\
\text { Nominations } \\
\text { and } \\
\text { remunerations } \\
\text { committees } \\
\text { Chapter 5: Audit } \\
\text { committee }\end{array}$ & $\begin{array}{l}\text { Regulated under } \\
\text { Principle } \\
\text { Setting up } \\
\text { Nominations and } \\
\text { remunerations } \\
\text { committee } \\
\text { Principle 1: Audit } \\
\text { committee }\end{array}$ & $\begin{array}{l}\text { Regulated } \\
\text { under } \\
\text { Principle 11: } \\
\text { Setting up } \\
\text { remunerations } \\
\text { and } \\
\text { nomination } \\
\text { committees } \\
\text { Principle 10: } \\
\text { Audit } \\
\text { committee } \\
\text { and internal } \\
\text { control }\end{array}$ & \\
\hline $\begin{array}{l}\text { BoD should have access to } \\
\text { accurate, relevant and timely } \\
\text { information }\end{array}$ & Regulated by Article 43 & $\begin{array}{l}\text { Regulated by Article } \\
40\end{array}$ & $\begin{array}{l}\text { Regulated } \\
\text { Chapter } 3\end{array}$ & $\begin{array}{l}\text { Regulated } \\
\text { Principle } 1\end{array}$ & $\begin{array}{l}\text { Regulated by } \\
\text { Principle } 4\end{array}$ & $\begin{array}{l}\text { Regulated } \\
\text { Article } 11\end{array}$ \\
\hline $\begin{array}{l}\text { Developing } \text { and training } \\
\text { employee representatives on } \\
\text { BoD }\end{array}$ & Article 43 & $\begin{array}{l}\text { Regulated by Article } \\
39\end{array}$ & $\begin{array}{l}\text { Regulated by } \\
\text { Chapter } 11\end{array}$ & $\begin{array}{l}\text { Regulated } \\
\text { Principle } 4\end{array}$ & Not regulated & Not regulated \\
\hline
\end{tabular}




\section{References}

Aldin, H., Malkawi, A., Pillai, R., \& Bhatti, M. I. (2014). Corporate governance practices in emerging markets: The case of GCC countries. Economic Modelling, 38, 133-141. https://doi.org/10.1016/j.econmod.2013.12.019

Alzahrani, Y. A. (2013). The Corporate Governance in Saudi Listed Companies. International Journal of Humanities and Management Sciences (IJHMS), 1(4), 243-245.

Capital Markets Authority. The Executive By Laws, Model Fifteen: Corporate Governance, Kuwait. Retrieved 4 January 2018, from https://www.cma.gov.kw/pdfviewer/?file=/documents/20622/453321/Module+15+-+June+2017/67d8bf70-2764 -46c2-bea2-f0d0c487e704\#page=1\&zoom=page-fit,-22,849

Cossin, D., \& El-Agamy, H. (2011). A Practical Perspective: Towards a Second Wave of Corporate Governance. $\begin{array}{llll}\text { Retrieved } & \text { January } & \text { 2018, from }\end{array}$ https://www.researchgate.net/publication/318259329_A_Practical_Perspective_Towards_a_Second_Wave_of_ Corporate_Governance

Dechert LLP. (2017). Saudi Arabia Approves New Corporate Governance Regulation. On Point/ A legal update. $\begin{array}{lllll}\text { Retrieved } & 4 & \text { January } & \text { 2018, from }\end{array}$ https://info.dechert.com/10/8338/march-2017/saudi-arabia-approves-new-corporate-governance-regulations(1).a sp?sid=01da7158-da60-47bc-ad0f-753477ff4453

European Corporate Governance Institute (ECGI). (2017). Retrieved 4 January 2018, from http://www.ecgi.org/codes/index.php

Fitch Ratings. (2014). Weak Governance Weighs on Ratings of GCC Privately-Owned Corporates. press release. Retrieved 18 January 2018, from https://www.fitchratings.com/site/pr/879134

Hussainey, K., \& Al-Nodel, A. (2008). Corporate governance online reporting by Saudi listed companies. In Tsamenyi, M., \& Uddin, S. (Eds.), Corporate Governance in Less Developed and Emerging Economies (Research in Accounting in Emerging Economies, Vol. 8, pp. 39-64). Emerald Group Publishing Limited. https://doi.org/10.1016/S1479-3563(08)08002-X

IMF. (2014). Economic Diversification in the GCC: Past, Present, and Future. IMF Staff Discussion Note, Dec. 2014. Retrieved 4 January 2018, from https://www.imf.org/external/pubs/ft/sdn/2014/sdn1412.pdf

IMF. (2016). More Bang for the Buck in the GCC: Structural Reform Priorities to Power Growth in a Low Oil Price Environment. Prepared by IMF Staff, Presented at the Annual Meeting of Ministers of Finance and Central Bank Governors October 26, 2016, Riyadh, Saudi Arabia, Oct. 2016. Retrieved 18 January 2018, from https://www.imf.org/external/np/pp/eng/2016/102616a.pdf

KSA's Capital Market Authority. (2017). Corporate Governance Regulations, issued by the Board of the Capital Market Authority Pursuant to Resolution Number (8-16-2017) Dated 16/5/1438H corresponding to 13/2/2017G. $\begin{array}{lllll}\text { Retrieved } & 4 & \text { January } & 2018, & \text { from }\end{array}$ https://cma.org.sa/en/RulesRegulations/Regulations/Documents/CGRegulations_en.pdf

Kumar, R., \& Sharma, V. (2006). Auditing: Principles and practice. New Delhi: PHI Learning Pvt. Ltd., India.

Kuwait Ministry of Commerce and Industry. (2016). Law No. 1 of 2016 on the Promulgation of the Companies Law. $\begin{array}{lllll}\text { Retrieved } & 4 & \text { January } & \text { 2018, } & \text { from }\end{array}$ http://www.kbc.gov.kw/Files/Decisionsandlaws/d4069db7-74a1-46fd-adf8-a0c7b3c75df3.pdf

Ministry of Industry and Commerce. (2010). Corporate Governance Code in Kingdom of Bahrain. Retrieved 4 January 2018 , from http://www.moic.gov.bh/En/Commerce/DomesticTrade/Corporate\%20Governance/Documents/bb9903e050a24f c6b65190cfcd637cd1BahrainCGCodeEN.pdf

Nobanee, H., \& Ellili, N. O. (2014). The Impact of the Mandatory Corporate Governance Disclosures on the Banking Growth in UEA: Islamic Versus Conventional Banks. Corporate Ownership \& Control, 12(1), Fall, 717-722. https://doi.org/10.22495/cocv12i1c8p4

Nobanee, H., \& Ellili, N. O. (2016, March). Corporate Sustainability Disclosure in Annual Reports: Evidence from UAE Banks: Islamic versus Conventional. Renewable \& Sustainable Energy Reviews, 55, 1336-1341. https://doi.org/10.1016/j.rser.2015.07.084 
Oman's Capital Markets Authority. (2015). Code of Corporate Governance for Publicly Held Joint Stock Companies in July 2015. Retrieved 4 January 2018, from https://cma.gov.om/Home/CircularFileDownlad/5308

Organization for Economic Co-operation and Development (OECD). (2015). G20/OECD the Principles of Corporate Governance. https://doi.org/10.1002/bl.30032

Qatar Financial Market Authority. (2009). Corporate Governance Code for Companies Listed in Markets Regulated by Qatar Financial Markets Authority. Retrieved 4 January 2018, from http://www.ecgi.org/codes/search_code.php?country=Qatar

Qatar Financial Market Authority. (2016). Governance Code for Companies \& Legal Entities Listed on the Main $\begin{array}{lllll}\text { Market. } & \text { Retrieved } & \text { January } & \text { 2018, from }\end{array}$ https://www.qe.com.qa/documents/20181/458121/Corporate+Governance+-+QFMA.pdf/c108b916-c0a1-b4fc-d 6f7-3efe7e0fce75

S\&P Global Ratings. (2017). Lagging Corporate Governance Still The Achilles' Heel Of Gulf Companies. Retrieved 4 January 2018, from https://www.globalcreditportal.com/ratingsdirect/renderArticle.do?articleId=1793821\&SctArtId=416672\&from $=$ CM\&nsl_code=LIME\&sourceObjectId=9963118\&sourceRevId=1\&fee_ind=N\&exp_date=20270214-03:00:2 9

Saidi, N., \& Kumar, R. (2007). Corporate Governance in the GCC. Working Paper, Hawkamah Institute for corporate governance, DIFC, Dubai.

Shehata, N. F. (2015). Development of corporate governance codes in the GCC: an overview. Corporate Governance, 15(3), 315-338. https://doi.org/10.1108/CG-11-2013-0124

Statistics Portal. (2017). Average annual OPEC crude oil price from 1960 to 2017 (in U.S. dollars per barrel). $\begin{array}{lllll}\text { Retrieved } & 4 & \text { January } & 2018, & \text { from }\end{array}$ https://www.statista.com/statistics/262858/change-in-opec-crude-oil-prices-since-1960/

The UAE Federal Government. (2015). Commercial companies law issued by federal law No. 2 of 2015 . Ar., Official Gazette, 575 of 2015, UAE.

The UAE's Securities and Commodities Authority (SCA). (2016). Board of Directors' Resolution No. (7 R.M) of 2016 Concerning the Standards of Institutional Discipline and Governance of Public Shareholding Companies. Published by Dubai Financial Market. Retrieved 4 January 2018, from http://www.dfm.ae/docs/default-source/Rules/the-chairman-of-authority-s-board-of-directors-resolution-no-(7-r$\mathrm{m}$ )-of-2016-concerning-the-standards-of-institutional-discipline-and-governance-of-publish-shareholding-comp anies.pdf?sfvrsn=2 